$\mathrm{Oz}$

Volume 8

Article 18

$1-1-1986$

\title{
A Camp for the New Boston Cooperative: Cuyler, New York
}

Russell Hamlet

Follow this and additional works at: https://newprairiepress.org/oz

Part of the Architecture Commons

(c) (i) (9)

This work is licensed under a Creative Commons Attribution-Noncommercial-No Derivative Works 4.0 License.

\section{Recommended Citation}

Hamlet, Russell (1986) "A Camp for the New Boston Cooperative: Cuyler, New York," Oz: Vol. 8.

https://doi.org/10.4148/2378-5853.1126

This Article is brought to you for free and open access by New Prairie Press. It has been accepted for inclusion in Oz by an authorized administrator of New Prairie Press. For more information, please contact cads@k-state.edu. 


\section{A Camp for the New Boston Cooperative}

Cuyler, New York

\section{Russell Hamlet}

Critics: Bob Burnham

Ray Streeter

The New Boston Cooperative is an association of farmers, homesteaders and fellow travelers founded in the 1930's as a last ditch-attempt to preserve the traditional rural lifestyle of the region. Today members are welleducated refugees from the cities and suburbs with the same central purposes. It is the cooperative's goal to inform the public about ecological concerns and to promote the economic growth of the area in ways which are environmentally sound. Programs the Cooperative plans to offer are organic homesteading, commercial organic dairy farming, ecological workshops and a variety of weekend seminars. The Coop will also provide activities for youth camps, retreats and private group recreation.

The camp is located in a rural area on the outskirts of Cuyler, New York, forty miles southeast of Syracuse. The surrounding landscape is heavily forested and seems remote because of the hilly terrain and winding roads which traverse it. Small pockets of commercial dairy farms and a variety of homesteaders, or part-time farmers, inhabit the area. The building site is on a tract of land acquired by the cooperative in recent years. Existing structures on the site are the New Boston Church and a barn to be used as a maintenance facility.

The design uses a spinal spatial order which is developed from the administration building to the cabins. Formal and informal spaces are created along this spine to distinguish between the public

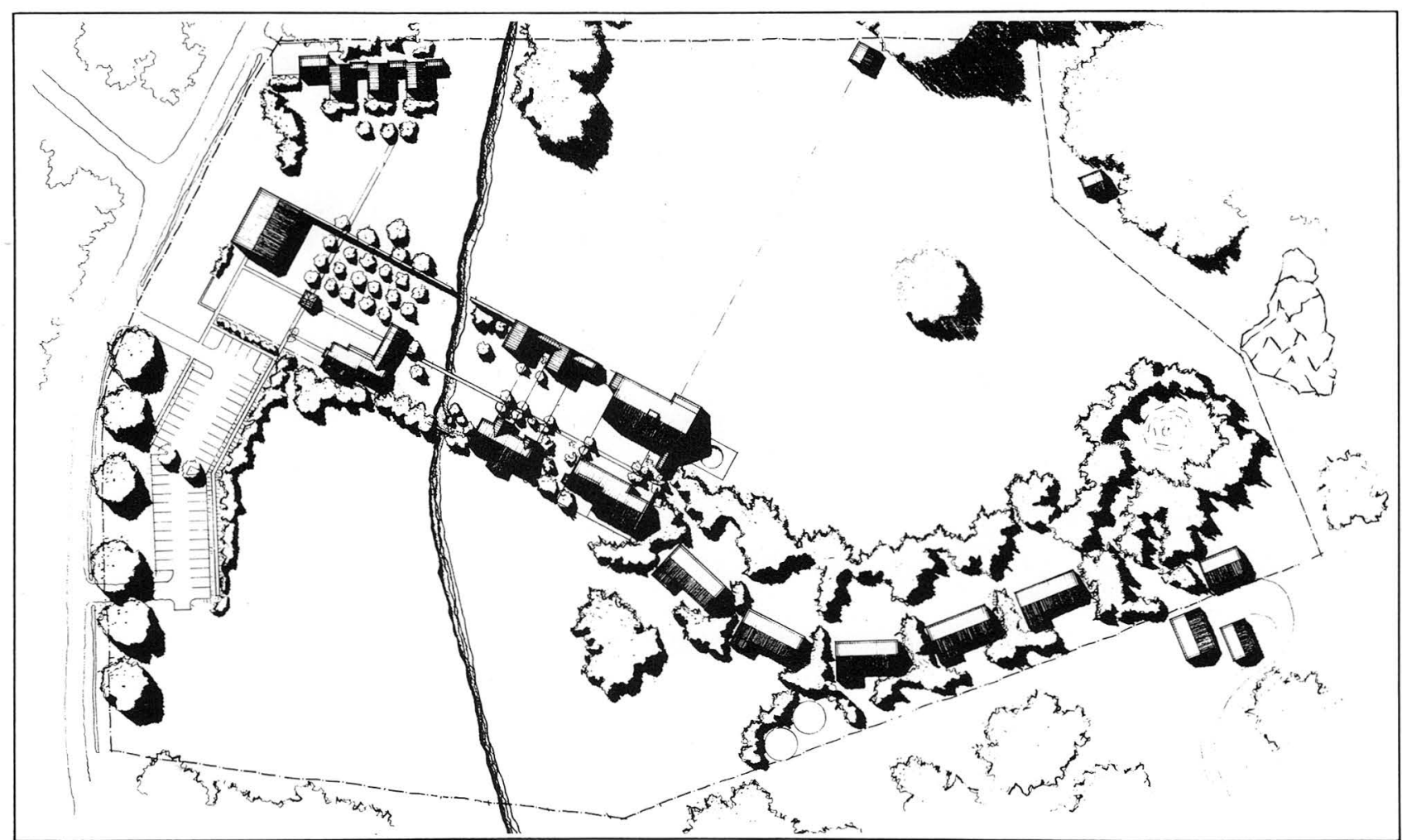

Site plan.

and private areas. A farmyard metaphor was developed to unify the camp and create a strong sense of place. This metaphor is apparent in the building details and the landscaping. Buildings are given elements that elude to barns and sheds while the landscape is cultivated with gardens and orchards.

The administration building was devloped in response to energy considerations as well as the farm metaphor; its barn door provides the main entry gate to the camp. The recreation space was developed as the main barn building with its massive size and cupola, while a circular swimming pool on the east side eludes to the ruinous foundation of an old grain silo. Massing of the classroom building resembles a small barn. Rooms have large barn doors that provide a strong relationship between the interior and exterior, which allows for demonstrations to be presented in either an indoor or an outdoor setting. On the east side of the classroom is a greenhouse which allows for the cultivation of food year-round. Housing units are on a less formal path and gesture to a typical farmhouse image. By incorporating passive solar strategies, units become energy responsive, allowing year-round occupancy.

This camp provides the New Boston Cooperative with the facilities to support a wide range of activities. The buildings compliment the image of the cooperative and serve as an asset to the surrounding community. The New England farm metaphor generates a strong sense of place which does not exploit the landscape and is in keeping with the cooperative's goal of protecting traditional rural lifestyles. 

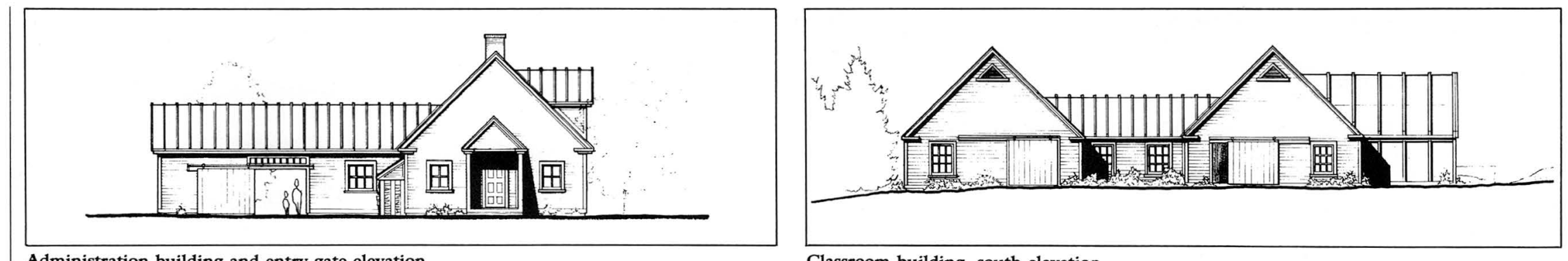

Administration building and entry gate elevation.

Classroom building, south elevation.

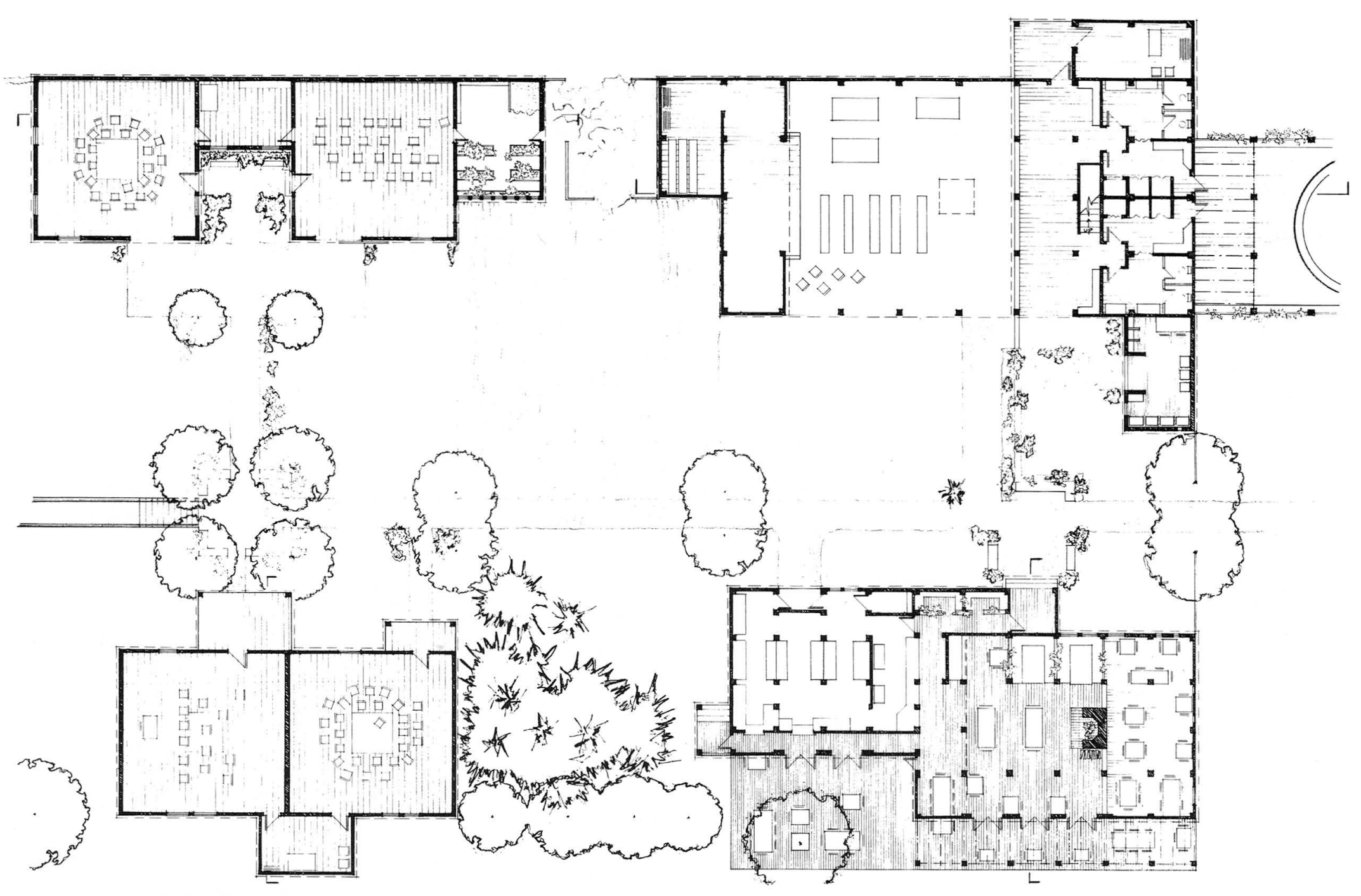

Classrooms, recreation hall and dining hall plans.

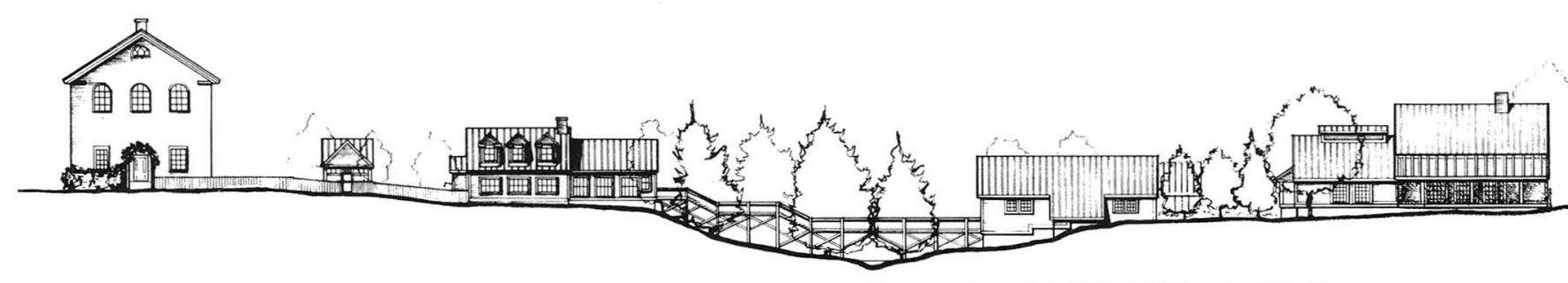

